\title{
NEGATIVE CORRELATION OF DIFFERENCE FORMULATION ON LEGAL STANDING IMPLEMENTATION OF JUDICAL REVIEW IN THE SUPREME COURT ${ }^{\Omega}$
}

\author{
Kartono \\ Law Faculty of Universitas Jenderal Soedirman Purwokerto \\ E-mail: kartonogs@ymail.com
}

\begin{abstract}
Legal certainty in the form of legislation, among others, can be shown by the consistency of the formulation of legal norms with the sub ordinate regulations. Therefore, the study on the influence of different formulations of the norm in the implementation of the law needs to be done. Evidently, the different formulations of the norm of the applicant's position as a legal entity has the right to a judicial review against the decision of a negative correlation, ie, the emergence of disparity in the results of the trials. Event rigger rejection of either party litigants.
\end{abstract}

Keywords: judicial review, legal certainty, the Supreme Court

\begin{abstract}
Abstrak
Kepastian hukum dalam pembentukan peraturan perundang-undangan antara lain dapat ditunjukkan dengan konsistensi formulasi norma undang-undang dengan peraturan pelaksana. Oleh sebab itu, kajian terhadap korelasiformulasi hukum yang berbedadalam pelaksanaan aturan hukum perlu dilakukan. Terbukti, perbedaan formulasi kedudukan badan hukum sebagai pemohon hak uji materiil berkorelasi negatif terhadap isi putusan, yakni timbulnya disparitas hasil pemeriksaan pengadilan. Bahkan memicu penolakan putusan dari para pihak berperkara.
\end{abstract}

Kata kunci: hak uji materiil, kepastian hukum, Mahkamah Agung

Introduction

Article 28D paragraph (1) The 1945 Constitution of the Republic of Indonesia stated that the right of everyone to recognition, guarantess, protection, and legal certainty in a fair and equal treatment before the law. The assertion above can be connected with the obligations of common regulation in the context of the protection of human rights. The protection and fulfilment the human rights in the country's law (rechtsstaat) also requires the principle of the legality of act of the Government (wet en rechtmatigheid van bestuur) in which the law must be positive.

The law makers when formulating provision in legislation should pay attention to the aspect of legal certainty and the protection of the rights of citizens. ${ }^{1}$ Defina Gusman stated

$\Omega \quad$ This article is part of dissertation research funded by DIPA Universitas Jenderal Soedirman through doctoral that to development of law in Indonesia which is already longstanding requires fundamental evaluation againts the law model which was formed as a means of community renewal by creating fairness and legal certainty. If not, the result will not run effectively because society does not reflect aspirations. ${ }^{2}$

The role of government and the courts are very important to maintain the legal certainty. They should not publish the implementation of which is not regulated in the law or contradicted to law. Through legal certainty individual security can be maintained from arbi-

dissertation grant scheme based on research activities agreement No. 66/UN23.10/PN/2013, on May $6^{\text {th }} 2013$.

Kartono, 'Politik Judicial Review di Indonesia', Jurnal Dinamika Hukum, Vol. 11 Special Edition, February 2011, Purwokerto: Law Faculty of Universitas Jenderal Soedirman, page 16 .

Delfina Gusman, "Problematika dalam Pembentukan Peraturan Perundang-undangan di Indonesia", Jurnal Yustisia, Volume 19 No 1, March 2012, Surakarta: Law Faculty of Universitas Sebelas Maret, page 17. 
tariness of the government and it can be known what to be charged or against individual countries do. ${ }^{3}$ This statement brings the consequence on the formation of legislaton must be based on law, and must not be contradicted to the law.

The need to maintain consistency of legislation can be done through the mecanism of supervision and regulations under the Act againts the law. Supervison is carried out with the aim of aligning the will Act with the regulations below which can be detrimental to society and is done through the mechanism of judical review (HUM). After Constitution Amandement 1945, the kind of mechanism has been shifted from the juridical authority based on Law No.14 Year 1985 into constitutional authority MA based Article 24 The 1945 Constitution of the Republic of Indonesia.

Constitutional authority MA that examines the legislation under the Act towards the law through HUM mechanism demands material and formal law arrangements as the ground of the test. The material law politics created Law No. 3 of 2009 about second amendment of Law No. 14 of 1985 on the Supreme Court. Meanwhile, the political provisions of HUM formal law created the Regulations of Supreme Court (Perma) No.1 Year 2011 concerning Judicial Review. In fact, there is a difference in the formulation of a legal product in two setting above. Differences occur in the formulation of legal standing arrangements are legal entities which can be traced from article 1 point (4) Perma No. 1 Year 2011 with the article 31 of Law No. 3 Year 2009. Article 1 point (4) Perma No. 1 Year 2011:

The applicant's objection is 'community groups' or 'individual' who apply for objections on the Supreme Court over the introduction of lower-level regulations of the law.

The foregoing sets out two qualifying applicant a HUM is entitled to act as the HUM ap-

Peter Mahmud Marzuki, 2009, Pengantar Ilmu Hukum, $1^{\text {st }}$ Edition, $2^{\text {nd }}$ Printing, Prenada Media Kencana, Jakarta, page 159-160. plicant, namely groups of people or individuals. While, different formulations is formulated in Law No. 3 Year 2009. Article 31A paragraph (1) and (2) of Law No. 3 Year 2009 are:

(1) Legislation testing applicat-ion under the law towards the law is submitted directly by the applicant or his power to the Supreme Court and written in Indonesian;

(2) The application as referred in paragraph (1) may only be carried out by a party that considers its rights harmed by the enactment of regulations under the law, namely :

(a) An individual citizen of Indonesia;

(b) The unity of community law all still alive and in accordance with the development of society and the principle of the Unitary State of the Republic of Indonesia regulated in law; or

(c) Public or private legal bodies.

Article 31A paragraph (22) of Law No. 3 Year 2009 explicitly confirms three qualifications of HUM applicant, namely: individuals, legal entities of community, and legal bodies (public/private). Meanwhile, Article 1 paragraph (4) Perma No.1 Year 2004 only reaches a qualifying applicant limited to what is set in paragraph (2) point $a$ and point $b$ of Law No.3 Year 2009, namely the individual applicant or the unity of legal communities.

HUM mechanism intrinsically has become a part of effort and process to reinforcement of lawstate principle that set the Law as the highest law juridicially. This opinion is inline with tiered norms theory stated by Hans Kelsen that relations between norms that regulate the other norms making can be called as super and subordination relations in spatial context. Norms that determine the making of norms are superior, while formed norms are inferior. These norms are arranged by facts that lower norms making is determined by higher norms. ${ }^{4}$

\footnotetext{
4 Compare with Janpatar Simamora, "Analisa Yuridis Terhadap Model Kewenangan 'Judicial Review' di Indonesia”, Jurnal Mimbar Hukum, Vol. 25 No. 3, October 2013, Yogyakarta: Law Faculty Universitas Gadjah Mada, page 390 .
} 
Ironically, different regulation as noted above actually occurs in the underlying provisions of judicial procedure law by a judicature. Law mechanism on which to base in maintaining consistency system of norm, so that study of the correlation differences formulations with the implementation of testing needs to be done.

\section{Problems}

Based on case above, problems which is formulated on this study is wether regulation of legal standing of institution has a negative correlation with the implementation of the HUM in the supreme court?

\section{Research Method}

This research is a law (legal research) which is related to the rules applying of countries which gives the study normative as research. Data were obtained from both primary data and secondary data. The primary data obtained through interviews with several sources obtained by purposive, they are 1 (person) from superm court and 1 (person) from Indonesian Center for Environmental Law (ICEL). Determination purposively towards environmental organization based on the consideration that the approach is related to the testing regulations of law of natural resources. The determination of two sources is considered quite. Selected normative approach gives the reason that primary data become advocates for the secondary data as the main data. Data were collected through interviews with pre-determined guidelines.

Secondary data consists of primary legal substances and secondary legal substances. Primary legal materials derived from law and court decisions, whereas the secondary legal materials obtained from text books or journals which is relevant. Secondary data changed into primary data and collected with consideration of relevance data of problems. The data is analysed qualitatively-interpretively. Qualitative analysis is performed on primary data obtained from sources, while interpretive analysis is performed on data laws. Interpretive analysis is used mainly systematic analytical with syste- matize several interrelated normative provisions and valid in procedural law of HUM.

\section{Discussion}

Negative correlation of differences formulation on legal standing implementation of judical review in the supreme court.

Many critics showed distrust towards law enforcements on verdict giving in court. This is evidenced by the number of complaints against the decision is deemed not reflect the rule of law, justice and expediency. ${ }^{5}$ The job of the judge demanded high responsibility so that the court decision which is stated with "For the Sake of Justice under the One Almighty God" shows the obligation to enforcing the law, the truth and justice that must be accounted horizontally to humans, and vertically to Almighty God. ${ }^{6}$

The teaching of the ideal of the law (Ide des Recht) mention of the three ideals of the law must be proportionately, namely legal certainty (rechtssicherkeit), Justice (gerechtigkeit) and benefit (zweckmasigkeit). If it is associated with the theory of law enforcement as presented bt Gustav Radbuch in idee des recht, law enforcement must meet the third principle. ${ }^{7}$ The Justiciabellen generally crave the matters submitted to the Court can be professional judges were disconnected and have high moral integrity, so that as to bring decision that containing legal certainty and fairness. ${ }^{8}$

The question of the difference in formulation of arragements with regard to the issue of legal certainty can be promoted the issue of disparity and the refusal of the ruling party liti-

5 Tata Wijayanta dan Herry Firmansyah, "Perbedaan Pendapat Dalam putusan-Putusan Di Pengadilan Negeri Yogyakarta dan Pengadilan Negeri Sleman", Jurnal Mimbar Hukum, Vol. 23 No. 1 February 2011, Yogyakarta: Law Faculty of Universitas Gadjah Mada, page 46.

6 Dudu Duswara Machmudin, "Mengembalikan Wibawa Mahkamah Agung Sebagai Peradilan Yang Agung", Jurnal Konstitusi, Vol. 10 No. 1 March 2013, Jakarta: Mahkamah Konstitusi, page 39.

7 Fence M. Wantu, "Antinomi Dalam Penegakan Hukum Oleh Hakim", Jurnal Mimbar Hukum, Vol.19 No. 3 October 2007, Yogyakarta: Law Faculty of Universitas Gadjah Mada, page 395.

8 Bambang Sutiyoso, "Mencari Format Ideal Keadilan Putusan dalam Peradilan”, Jurnal Hukum, Vol. 17 No. 2, April 2010, Yogyakarta: Law Faculty of Universitas Islam Indonesia, page 221. 
gants. Case in of HUM, the verdict of the disparity can be seen from the judge's legal reasoning about the relvance of the legal standing of the applicant legal entity as a result of the examination session. It can be confirmed by the following table : 9

Table 1. Legal considerations the legal standing that disparity the applicant of HUM legal entity (2000 s.d 2010)

\begin{tabular}{|c|c|c|c|c|}
\hline \multirow[t]{2}{*}{ No } & \multirow[t]{2}{*}{ No Case } & \multirow[t]{2}{*}{$\begin{array}{l}\text { Legal Entity Applicant } \\
\text { (Public/Private) }\end{array}$} & \multicolumn{2}{|c|}{$\begin{array}{l}\text { Legal Con- } \\
\text { sideration of } \\
\text { Applicant }\end{array}$} \\
\hline & & & Yes & No \\
\hline 1 & 09P/HUM/2002 & Kab. Gresik & S & - \\
\hline 2 & 01G/HUM/2004 & PT Charoen Phokpand & - & 2 \\
\hline 3 & 08P/HUM/2004 & Kab. Kotawaringan & - & T \\
\hline 4 & 14P/HUM/2004 & Kab. Gresik & - & J \\
\hline 5 & 29P/HUM/2004 & PT. SMM & - & L \\
\hline 6 & 17P/HUM/2005 & Kota Bandung & - & J \\
\hline 7 & 20P/HUM/2007 & Kab. Nlas & T & - \\
\hline 8 & 23P/HUM/2009 & Kab. Kutai Timur & J & - \\
\hline \multicolumn{3}{|c|}{ Total } & 3 & 5 \\
\hline
\end{tabular}

The table above shows the disparity of judge to considering legal standing of applicant legal entity during investigation session. Based on the data, there is the fact from 8 (eight) cases that have investigated, only three cases or 37,50 percent which the legal standing of applicant is to be considered in the session. While five cases or 62.50 percent were not considered.

The data of table shows that in the decision more panel of judges did not consider the legal standing of applicant legal entity. That's tendeny can be associated with the different formulations the procedural law of the rights of judicial review, and Supreme Court regulation No. 1 Tahun 2011 which unexplicitly obliges the judge to test the applicant legal standing during investigation cases.

The lack of consideration legal standing of the rights of judicial review applicant, opens opportunities to rejection the decision of the court by the parties litigant. This constatation (draw a conclusion) can be shows in the case decision of No. 29.P/HUM/2004. This case essentially contains the petition for cancellation of the Minister of Forestry (defendant) decision who converts a number of protected forest

\footnotetext{
${ }^{9}$ Source: Processed by the primary legal materials.
}

areas into a conservation area by the name of Batang Gadis National Park. Conversion of land covering some parts of the contract work the applicant rights of judicial review, namely Sorikmas Mining of Company Feltered as an applicant who obtained the contract work for exploration of gold mining in Mandailing Natal district, North Sumatra.

The denial is done through two attempts objections by the applicant so that the decision can be reviewed. In objection that has been sent by letter Numb. S.395/Menhut-II/2009 in 25 May 2009, the defendant ask the Supreme Court to cancel the decision and/or instructed back the judge to check the case. One of the reasons to raised the objections are the subject of law who eligible to submit of petition just the 'community' or 'individual'. In reality, the applicant who objection the rights of judicial review is Sorikmas Mining Company Feltered, legal entities that are not accessible as an applicant rights of judicial review under Article 1 paragraph (4) supreme court regulation Number 1 Year 2011.

Similar objections also expressed by the Executive Director of Indonesian Center for Environmental Law (ICEL), Rhino Subagyo. According to the above cases panel of judge did not test and consider standing/right to sue from the applicant's objection, whether it qualifies as the provisions of supreme court regulation or not. The cancellation of court decision by the defendant shows the distrust of parties are concern with accountability court decision. ${ }^{10}$

Judge judicial field the State Administration Supreme Court Maftuh Effendi stated that mostly consideration of judge about the legal standing in the decision of right to judicial review did not show the consideration in legal sufficient. Even in some of the decisions is found without the given of consideration regarding the juridical arguments why the applicant has standing in judicial. ${ }^{11}$ This statement un-

10 Rhino Subagyo, 'Indonesian Center for Environmental Law (ICEL)', Interview March 6 ${ }^{\text {th }} 2012$.

11 Maftuh Efendi, Hakim Yustitisial Kamar Tata Usaha Negara Mahkamah Agung, Interview, August 26 2013 
derlines reality that many rights of judicial review decision does not consider the applicant's legal standing. If any consideration which has been done is often inadequate in terms of juridical arguments.

Maftuh Effendi also said that many things that should be considered in the decision of implementation of rights judicial review, but not considered adequately, as the applicant legal standing. This tendency is due to many applicants who did not attach the terms of a formal petition such copy of valid ID card for the individual applicant, or deed of legal entity to the applicant legal entity so that the legal considerations often done as it is. ${ }^{12}$

That statement confirmed the reality of the problems investigation session caused by the problem of different formulations of legal regulation can be developed more widely, because the procedural law rights of judicial review has not set the detailed formal requirements that must be satisfied by the applicant of rights of judicial review. Differences in regulation is raising act of the applicant to submit rights of judicial review petition with the potluck provision, so that causing difficulties in the investigation session of court.

Judicial review rights become is an important part of efforts to strengthen the principle of legality validity of acts of government, because the decisions that has made will becoming the basis for the government organ in serving the public. Public services must also include the legal services by judicial institutions. Professional service and quality become the main instrument for the public welfare in the concept of welfare state country that aspired by the Indonesian people in the constitution. ${ }^{13}$ Therefore, the discourse of difference legal position regulation of applicant legal entity in the case of rights of judicial review should not be an obstacle of judge to apply the principle of legal certainty in judicial practice. Adequate

12 Maftuh Efendi, Interview, August 26 2013.

13 Nuriyanto, "Perkembangan Pelayanan Publik di Indonesia, Sudahkan Berlandaskan Konsep Welfare State?", Jurnal Konstitusi, Vol. 11 No. 3, September 2014, Mahkamah Konstitusi Jakarta, page 433. legal considerations in the decision of gives positive implications for accountability of the decision to the truth material of the decision.

\section{Overcoming The Difference Formulation Procedural Law of Judicial Rights}

Law enforcement can begin by notice the role of law enforcement. The key point in understanding the good law enforcement is the understanding of the principles in it. ${ }^{14}$ Therefore, the different formulations of Law No. 3 Year 2009 with Supreme Court regulation No. 1 The Year 2011 actually can be handled by the legal principle of lex superiori derogat legis inferiori. However, the law principle is actually not the law itself. The principle of law is only the tendency and general instructions for the establishment of a law based on a sense of decency that evolved in society. ${ }^{15}$

The law reality often showed there is public distrust in judicial power, because one of the main factors is the decision of the judge that has not reflect the value of legal certainty for litigants coveted. ${ }^{16}$ To prevent or eliminate the problems in the test, the judge should be based on the basic idea of the state of law, the guarantee of legal certainty as a human right which is guaranteed by Article 28D (1) The Constitution of 1945. The basic idea of this law states obliges the judge for continue to consider the applicant's legal standing and provide sufficient arguments. The building logic of argumentative law, as well as legal reasons that can be accountable no need to bring the different laws formulations that existing as a constraint in achieving a quality court decision.

14 Kusnu Goesniadhie S, "Perpektif Moral Penegakan Hukum yang Baik", Jurnal Hukum lus Quia lustum, Vol. 17 No. 2, April 2010, Yogyakarta: Law Faculty of Universitas Islam Indonesia, page 205.

15 Tata Wijayanta, "Asas Kepastian Hukum, Keadilan dan Kemanfaatan dalam Kaitannya dengan Putusan Kepailitan Pengadilan Niaga", Jurnal Dinamika Hukum, Vol. 14 No. 2, Mei 2014, Purwokerto: Law faculty of Universitas Jenderal Soedirman, page 219

16 Fence M Wantu, "Mewujudkan Kepastian Hukum, Keadilan dan Kemanfaatan dalam Putusan Hakim di Peradilan Perdata", Jurnal Dinamika Hukum Yustisia, Vol. 12 No. 3, September 2012, Purwokerto: Law Faculty of Universitas Jenderal Soedirman, page 480. 
The Supreme Court as judicial power executor often underwent a reform that is expected to grow steadily over time and affect the improvement of the quality of Supreme Court decision. ${ }^{17}$ The quality of Supreme Court decision that increased can strengthen the principle of judicial power that separate as mandated the State Constitution of Indonesia Year 1945. The separation was carried out by transferring organizational, administrative, financial and judicial institutions under of department initially became under the rule of Supreme Court. This was due to the passage of time more than three decades, the implementation of independent judicial power was not fully implemented well and accompanied by indications of irregularities provisions of legislation justice field. ${ }^{18}$

The legislation justice field should be able to provide a legal basis and legal certainty for the judge, so that the court decision can be easier to be predicted by justice seekers. Predictability requires that the law should be able to bring certainty. ${ }^{19}$ Legal certainty it can be done by setting a more complete of HUM procedural law at the level of legislation, so that it can eliminate the limitations and the different formulations of existing law. This alternative can be done by revising the legislation of Supreme Court and put HUM procedural law in the same chapter with any other applicable procedural law in Supreme Court.

\section{Conclusion}

The difference formulation legal standing regulation of legal entities in the procedural law of judicial review rights is proved negative correlation againts implementation in-

17 Nunuk Nuswardani, "Upaya Peningkatan Kualitas Putusan Hakim Agung dalam Mewujudkan Law dan Legal Reform", Jurnal Hukum, Vol. 16 No. 4, 16 Oktober 2009, Yogyakarta: Universitas Islam Indonesia, page 529.

18 Hadi Supriyanto, "Pemisahan Fungsi Kekuasaan Eksekutif dan Yudikatif", Jurnal Legislasi, Vol. 1 No. 1, July 2008, Jakarta: Badan Pembinaan Hukum Nasional Jakarta, page 1.

19 Saut P Panjaitan, "Politik Pembangunan Hukum di Bidang Investasi Suatu Keniscayaan Konstitusi Ekonomi”, Jurnal Konstitusi, Vol. 7 No. 2, April 2010, Jakarta: Mahkamah Konstitusi, page 56. vestigation of judge in Supreme Court. The author identified two negative correlation that can be shown. First, the different formulations setting legal standing of legal entities push the judge's decision disparities in considering the applicant's legal standing of legal entities in court. The data shows that judges tend not to consider the applicant's legal standing of legal entities in its decision. Second, the different formulations setting legal standing of legal entities in the procedural law judicial review rights also push on delegitimation quality of judge's decision as a free and independent power to trigger rejection by the court decision party litigant.

\section{Suggestion}

To overcome the disparity consideration the applicant's legal standing of legal entities in court of judicial review rights, can be offered two alternatives, there are: first, the need to revise the regulation of judicial review rights at the level of laws, namely the legislation. This kind of arrangement is intended to avoid differences in the formulation of specific legal provisions. This alternative can be done by revising legislation Supreme Court and put judicial review rights procedural law in the same chapter to another procedural law that applicable in Supreme Court. This suggestion is also associated with the fact that judicial review rights procedural law currently in force is the only law court proceedings that only regulated at the level of Perma, while other procedural law is set at the level of legislation.

Second, in the examination judicial review rights dispute, the judge must keep on the basic idea that bases on ideal of a state law which was based on equity and legal certainty. The basic idea is obliging judges to continuously observing all the legal standing of the applicant and provide adequate legal arguments in the verdict. Consideration that has been done undoubtedly can push the legitimation quality of judge decision as an independent judicial authority. 


\section{References}

Gusman, Delfina. "Problematikan dalam Pembentukan Peraturan Perundang-undangan di Indonesia". Jurnal Yustisia, Vol. 19 No. 1, March 2012. Surakarta: Faculty of Law, Universitas Sebelas Maret;

Kartono. "Politik Judicial Review di Indonesia". Jurnal Dinamika Hukum, Vol. 11 Special Edition, February 2011, Purwokerto: Law Faculty of Universitas Jenderal Soedirman;

Machmudin, Dudu Duswara. "Mengembalikan Wibawa Mahkamah Agung Sebagai Peradilan Yang Agung". Jurnal Konstitusi, Vol. 10 No. 1, March 2013. Jakarta: Mahkamah Konstitusi;

Marzuki, Peter Mahmud. 2009. Pengantar Ilmu Hukum. $1^{\text {st }}$ Edition, $2^{\text {nd }}$ printing. Prenada Media Kencana, Jakarta;

Nuswardani, Nunuk. "Upaya Peningkatan Kualitas Putusan Hakim Agung dalam Mewujudkan Law dan Legal Reform”. Jurnal Hukum, Vol. 16 No. 4, October 2009. Yogyakarta: Universitas Islam Indonesia;

Nuriyanto. “Perkembangan Pelayanan Publik di Indonesia, Sudahkan Berlandaskan Konsep Welfare State?". Jurnal Konstitusi, Vol. 11 No. 3, September 2014. Jakarta: Mahkamah Konstitusi;

Panjaitan, Saut P. “Politik Pembangunan Hukum di Bidang Investasi Suatu Keniscayaan Konstitusi Ekonomi”. Jurnal Konstitusi, Vol. 7 No. 2, April 2010, Jakarta: Mahkamah Konstitusi;

S, Kusnu Goesniadhie. "Perpektif Moral Penegakan Hukum yang Baik”. Jurnal Hukum lus Quia lustum, Vol. 17 No. 2, April 2010. Yogyakarta: Law Faculty of Universitas Islam Indonesia;

Simamora, Janpatar. “Analisa Yuridis terhadap Model Kewenangan 'Judicial Review' di Indonesia”. Jurnal Mimbar Hukum, Vol. 25 No. 3, October 2013. Yogyakarta: Law Faculty of Universitas Gadjah Mada;

Sutiyoso, Bambang. "Mencari Format Ideal Keadilan Putusan dalam Peradilan". Jurnal Hukum, Vol. 17 No. 2, April 2010. Yogyakarta: Universitas Islam Indonesia;

Supriyanto, Hadi. "Pemisahan Fungsi Kekuasaan Eksekutif dan Yudikatif". Jurnal Legislasi, Vol. 1 No. 1, July 2004. Jakarta: Badan Pembinaan Hukum Nasional;
Wantu, Fence M. “Antinomi dalam Penegakan Hukum oleh Hakim". Jurnal Mimbar Hukum, Vol. 19 No. 3 Oktober 2007. Yogyakarta: Law Faculty of Universitas Gadjah Mada;

“Mewujudkan Kepastian Hukum, Keadilan dan Kemanfaatan dalam Putusan Hakim di Peradilan Perdata”. Jurnal Dinamika Hukum, Vol. 12 No. 3 September 2012. Purwokerto: Law Faculty of Universitas Jenderal Soedirman;

Wijayanta, Tata. “Asas Kepastian Hukum, Keadilan dan Kemanfaatan dalam Kaitannya dengan Putusan Kepailitan Pengadilan Niaga”. Jurnal Dinamika Hukum, Vol. 14 No. 2 May 2014. Purwokerto: Law Faculty of Universitas Jenderal Soedirman;

Wijayanta, Tata dan Herry Firmansyah. "Perbedaan Pendapat dalam putusan-Putus-an di Pengadilan Negeri Yogyakarta dan Pengadilan Negeri Sleman”. Jurnal Mimbar Hukum,Vol. 23, No. 1 February 2011. Yogyakarta: Law Faculty of Universitas Gadjah Mada. 